\title{
PENINGKATAN HASIL BELAJAR SISWA DALAM OPERASI BILANGAN DENGAN MENGGUNAKAN GOOGLE MEET DI SEKOLAH DASAR
}

\author{
Nurul Adcha \\ Sekolah Dasar Negeri 014 Sungai Nyiur, Indragiri Hilir, Indonesia \\ nuruladhca@gmail.com
}

\begin{abstract}
ABSTRAK
Bencana pandemi Covid-19 juga telah menimbulkan dampak pada berbagai bidang, salah satu yang paling dirasakan adalah bidang pendidikan. Mulai dari pendidikan dasar hingga pendidikan tinggi, semuanya menjadi terhambat dan tidak bisa dilaksanakan secara tatap muka karena kerumunan dapat memperluas penyebaran virus Covid-19. Melakukan pembelajaran dengan daring menggunakan google meet. Google meet ini memungkinkan guru dan siswa untuk melakukan panggilan secara audiovisual dalam bentuk klasikal atau dalam jumlah banyak orang. Selain itu, aplikasi ini menyediakan banyak fitur yang dapat mendukung pelaksanaan pembelajaran secara daring. Jenis penelitian ini adalah Penelitian Tindakan Kelas (PTK) dengan menggunakan desain penelitian model Kemmis dan Mc. Taggart yaitu berbentuk spiral dari siklus yang satu ke siklus yang berikutnya. Setiap siklus meliputi planning (rencana), action (tindakan), observation (pengamatan), dan reflection (refleksi) (dalam Arikunto, 2002). Dua siklus yang memperlihatkan hasil belajar peserta didik dengan rata-rata yang meningkat dari 60.45 menjadi 80.45 . Dengan jenjang nilai dari 50 sampai dengan 100 . Pembelajaran yang dilakukan oleh guru menggunakan media google meet lebih efektif dalam meningkatkan hasil belajar siswa pada operasi bilangan matematika.
\end{abstract}

Kata Kunci: pandemi, google meet, tindakan kelas, hasil belajar

\section{IMPROVING STUDENTS' LEARNING OUTCOMES ON NUMBERING OPERATIONS THROUGH GOOGLE MEET AT ELEMENTARY SCHOOLS}

\begin{abstract}
The Covid-19 pandemic disaster has affected various fields; one of which was the field of education. Starting from basic education to higher education, everything is hampered and cannot be carried out face-to-face because crowds can expand the spread of the Covid-19 virus. Utilizing google meet is believed to be a strategy to conduct online learning. Google meet allows teachers and students to make audiovisual calls in a classical form or in large numbers. In addition, this application provides many features that can support the implementation of online learning. This type of research was Classroom Action Research (CAR). This research used a research design model of Kemmis and Mc. Taggart referring to a spiral from one cycle to the next cycle. Each cycle included planning,, action, observation, and reflection (in Arikunto, 2002). Two cycles resulted in the increase of students learning outcomes from 60.45 to 80.45 with grades from 50 to 100. Thus, learning through google meet media was more effective in improving students' learning outcomes in mathematical numbering operations.
\end{abstract}

Keywords: pandemic, google meet, class action, learning outcomes

\begin{tabular}{|c|c|c|}
\hline Submitted & Accepted & Published \\
\hline 12 September 2021 & 11 November 2021 & 27 November 2021 \\
\hline
\end{tabular}

\begin{tabular}{|l|l|c|cc|}
\hline Citation & $:$ & Adcha, N. (2021). Peningkatan Hasil Belajar Siswa Dalam Operasi Bilangan Dengan Menggunakan Google Meet Di \\
& & $\begin{array}{l}\text { Sekolah Dasar. Jurnal PAJAR (Pendidikan dan Pengajaran), 5(6), 1760-1766. DOI : } \\
\text { http://dx.doi.org/10.33578/pjr.v5i6.8582. }\end{array}$ \\
\hline
\end{tabular}

\section{PENDAHULUAN}

Dalam perkembangan zaman saat ini dan juga kebijakan pemerintah di masa pandemi covid-19 harus menerapkan pembatasan sosial untuk mencegah penyebaran virus corona. Hal tersebut sangat berpengaruh pada dunia pendidikan (Thowaf, 2018). Bencana pandemi Covid-19 juga telah menimbulkan dampak pada berbagai bidang, salah satu yang paling dirasakan adalah bidang pendidikan. Mulai dari pendidikan dasar hingga pendidikan tinggi, semuanya menjadi terhambat dan tidak bisa dilaksanakan secara tatap muka karena kerumunan dapat memperluas penyebaran virus Covid-19. Perubahan sistem pembelajaran dari luring (offline) menjadi daring (online) tentu saja tidak terlepas dari beberapa kendala yang dihadapi seperti ketidak siapan siswa 
terhadap perubahan sistem pembelajaran ini (Pernantah, Nova, Ramadhani, 2021).

Hal ini juga berpengaruh terhadap mata pelajaran yang akan diajarkan oleh guru, salah satunya merupakan pelajaran matematika. Matematika merupakan pelajaran yang akan dipergunakan dalam seluruh aspek kehidupan. Memiliki kemampuan memecahkan soal Matematika akan menjadi bekal bagi siswa untuk melakukan pemecahan masalah dalam menjalani kehidupan saat ini dan nanti (Koesmini, 2021). Dalam hal ini salah satu operasi hitung bilangan bulat, yang merupakan kompetensi dasar yang harus dikuasai oleh siswa, kenyataannya disekolah materi ini sulit dipahami oleh siswa, setelah diadakan post tes ternyata banyak siswa yang belum bisa mengerjakan dengan benar. Terlebih pada saat ini suasana covid 19 yang mengharuskan belajar dari rumah. Oleh karena itu penanganan masalah ini sangat mendesak untuk dicarikan solusinya agar prestasi siswa tahun ini dapat meningkat.

Untuk itu dalam upaya peningkatan kualitas sekolah, dan juga peningkatan hasil belajar siswa dalam pelajaran matematika, tenaga kependidikan sangat diharapkan berperan sebagaimana mestinya dan sebagai tenaga kependidikan yang berkualitas, dengan cara berinovasi pada masa pandemi ini. Serta aktif menggunakan teknologi salah satunya google meet.

Google meet merupakan media aplikasi untuk melakukan video conference. Google meet ini memungkinkan guru dan siswa untuk melakukan panggilan secara audiovisual dalam bentuk klasikal atau dalam jumlah banyak orang. Selain itu, aplikasi ini menyediakan banyak fitur yang dapat mendukung pelaksanaan pembelajaran secara daring. Pembelajaran online dengan memanfaatkan google meet mempermudah guru dalam memaparkan materi pembelajaran dan membangun kelas yang aktif kreatif dengan banyak berinteraksi dan berdiskusi dengan siswa maupun antar siswa. Sehingga tidak menutup peluang bahwa proses pembelajaran dapat efektif dilaksanakan meskipun secara daring (Pernantah, Nova, Ramadhani, 2021).
Tujuan umum dalam penelitian ini adalah untuk meningkatkan hasil belajar siswa terutama matematika dengan menggunakan google meet. Keefektifan belajar adalah satu standar mutu pendidikan dan sering kali diukur dengan tercapainya tujuan, yang diperoleh setelah pelaksanaan proses belajar mengajar, yang menyediakan kesempatan belajar sendiri atau melakukan aktivitas seluas-luasnya kepada siswa untuk belajar. Efektivitas pembelajaran dapat tercapai, salah satunya dengan menggunakan media dalam proses pembelajaran yang sesuai dengan situasi dan kondisi, baik dari konten materi ataupun keadaan lingkungan siswa. Meskipun terjadi perubahan pembelajaran dari tatap muka ke tatap layar, maka pembelajaran daring yang dilakukan saat ini harus diupayakan untuk terus efektif.

\section{METODE PENELITIAN}

Jenis penelitian ini adalah Penelitian Tindakan Kelas (PTK) dengan menggunakan desain penelitian model Kemmis dan Mc. Taggart yaitu berbentuk spiral dari siklus yang satu ke siklus yang berikutnya. Setiap siklus meliputi planning (rencana), action (tindakan), observation (pengamatan), dan reflection (refleksi) (dalam Arikunto, 2002).

Penelitian ini dilaksanakan pada bulan Januari sampai bulan Maret 2021. Subjek penelitian ini adalah peserta didik kelas III SDN 014 Sungai Nyiur Kecamatan Tanah Merah Kabupaten Indragiri Hilir, yang terdiri dari 11 peserta didik. Objek penelitian adalah peningkatan hasil belajar peserta didik. Teknik pengumpulan data menggunakan observasi dan wawancara. Instrumen yang digunakan tugas individu dalam pelajaran operasi bilangan matematika. Data dianalisis secara kuantitatif dan disajikan dalam bentuk tabel.

Secara rinci prosedur penelitian tindakan ini:

\section{Tahap Perencanaan}

Pada tahap perencanaan ini kegiatannya meliputi:

a. Peneliti dan pengamat menetapkan alternatif peningkatan efektivitas pembelajaran. 
b. Peneliti bersama-sama kolaborator membuat perencanaan pengajaran yang mengembangkan keterampilan intelektual.

c. Mendiskusikan tentang pembelajaran yang mengembangkan keterampilan intelektual siswa.

d. Menginventarisir media pembelajaran

e. Membuat lembar observasi.

f. Mendesain alat evaluasi

\section{Tahap Pelaksanaan Tindakan}

Kegiatanya adalah melaksanakan kegiatan pembelajaran sebagaimana yang telah direncanakan.

\section{Tahap Observasi}

Kegiatan yang dilaksanakan yaitu mengobservasi terhadap pelaksanaan tindakan dengan menggunakan lembar observasi yang telah dipersiapkan.

\section{Tahap Refleksi}

Kegiatannya yaitu meliputi analisis data yang diperoleh melalui observasi pengamatan.

\section{HASIL DAN PEMBAHASAN}

Berdasarkan pelaksanaan tindakan selama 2 siklus yang dilakukan sebanyak 12 kali pertemuan, diperoleh data bahwa hasil belajar siswa mengalami peningkatan. Peningkatan hasil belajar diketahui dengan menerapkan media pembelajaran google meet pada operasi bilangan matematika.

\section{Siklus I}

Pada perencanaan tahap siklus I guru membuat perangkat pembelajaran berupa RPP, LKPD, dan Media Pembelajaran yang memuat tindakan yang akan dilakukan dalam penelitian. Sedangkan untuk pelaksanaan dan hasil belajar dapat dilihat pada tabel berikut :

Tabel 1. Hasil Observasi Pelaksanaan Pembelajaran Siklus I

\begin{tabular}{|c|c|c|c|}
\hline No & Komponen Perangkat Pembelajaran & Muncul & Tidak muncul \\
\hline \multirow{7}{*}{1} & Kegiatan Pembuka & & \\
\hline & a. Membuka pembelajaran dengan doa dan salam & $\sqrt{ }$ & \\
\hline & b. Menyiapkan siswa secara fisik dan mental & $\sqrt{ }$ & \\
\hline & c. Memotivasi siswa. & & $\sqrt{ }$ \\
\hline & d. Menyampaikan apersepsi. & $\sqrt{ }$ & \\
\hline & e. Menyampaikan tujuan pembelajaran. & $\sqrt{ }$ & \\
\hline & f. Menyampaikan cakupan materi. & $\sqrt{ }$ & \\
\hline \multirow[t]{10}{*}{2} & Kegiatan Inti & & \\
\hline & $\begin{array}{l}\text { a. Menyampaikan materi sesuai dengan tujuan pembelajarandan } \\
\text { sistematis. }\end{array}$ & $\sqrt{ }$ & \\
\hline & b. Mengaitkan materi dengan realitas kehidupan. & $\sqrt{ }$ & \\
\hline & c. Menggunakan media dalam menyampaikan materi. & $\sqrt{ }$ & \\
\hline & $\begin{array}{l}\text { d. Melibatkan siswa untuk menjelaskan dan mengerjakan operasi } \\
\text { bilangan }\end{array}$ & $\sqrt{ }$ & \\
\hline & e. Adanya interaksi dalam pembelajaran & $\sqrt{ }$ & \\
\hline & $\begin{array}{l}\text { f. Memudahkan siswa untuk melakukan proses } \\
\text { mengamati berkaitan dengan operasi bilangan }\end{array}$ & & $\sqrt{ }$ \\
\hline & $\begin{array}{l}\text { g. emfasilitasi siswa untuk melakukan latihan dengansoal- } \\
\text { soal secara tertulis atau lisan. }\end{array}$ & $\sqrt{ }$ & \\
\hline & h. Guru memantau latihan yang dilakukan siswa & & $\sqrt{ }$ \\
\hline & $\begin{array}{l}\text { i. Mengkonfrimasi hal-hal yang belum diketahui siswadan } \\
\text { memberikan penguatan kepada siswa. }\end{array}$ & $\sqrt{ }$ & \\
\hline 3 & Kegiatan Penutup & & \\
\hline
\end{tabular}


Jurnal PAJAR (Pendidikan dan Pengajaran)

Volume 5 Nomor 6 November | ISSN Cetak : 2580 - 8435| | ISSN Online : 2614 - 1337

DOI : http://dx.doi.org/10.33578/pjr.v5i6.8582

\begin{tabular}{llcl} 
a. & Merangkum materi & $\sqrt{ }$ & $\sqrt{ }$ \\
b. & Guru melakukan refleksi terhadap pembelajaran. & $\sqrt{ }$ & \\
c. & Guru memberikan soal evaluasi. & $\sqrt{ }$ \\
\hline d. & Guru memberikan tindak lanjut. & $\sqrt{ }$ \\
\hline e. & Menutup pembelajaran dengan doa dan salam & \\
\hline
\end{tabular}

Pada akhir pembelajaran siklus I guru memberikan soal evaluasi, berikut disajikan hasil belajar siswa berdasarkan hasil soal evaluasi yang dikerjakan.

Tabel 2. Hasil Belajar Siklus I

\begin{tabular}{ccccc}
\hline No & Nilai (x) & $\begin{array}{c}\text { Frekuensi } \\
\text { (f) }\end{array}$ & $\mathbf{f x}$ & Presentasi \\
\hline 1 & 50 & 4 & 200 & $38 \%$ \\
2 & 75 & 3 & 225 & $28 \%$ \\
3 & 80 & 3 & 240 & $28 \%$ \\
4 & 85 & 0 & 0 & $0 \%$ \\
5 & 90 & 0 & 0 & $0 \%$ \\
6 & 100 & 0 & 0 & $0 \%$ \\
7 & 0 ( Tidak Menjawab) & 1 & 0 & $6 \%$ \\
& Jumlah & 11 & 665 & $100 \%$ \\
\hline & Rata-rata & 60.45 & \\
\hline
\end{tabular}

Siklus II

Adapun hasil observasi pada perencanaan tahap siklus II guru membuat perangkat pembelajaran berupa RPP, LKPD, dan Media
Pembelajaran yang memuat tindakan yang akan dilakukan dalam penelitian. Sedangkan untuk pelaksanaan dan hasil belajar dapat dilihat pada tabel berikut :

Tabel 3. Hasil Observasi Pelaksanaan Pembelajaran Siklus II

\begin{tabular}{llcl}
\hline No & Komponen Perangkat Pembelajaran & Muncul & Tidak muncul \\
\hline 1 & Kegiatan Pembuka & $\sqrt{ }$ \\
\cline { 2 - 3 } & a. Membuka pembelajaran dengan doa dan salam & $\sqrt{ }$ \\
\hline b. Menyiapkan siswa secara fisik dan mental & $\sqrt{ }$ \\
\hline c. Memotivasi siswa. & $\sqrt{ }$ \\
\hline d. Menyampaikan apersepsi. & $\sqrt{ }$ \\
\hline e. Menyampaikan tujuan pembelajaran. & $\sqrt{ }$ \\
\hline f. Menyampaikan cakupan materi. & \\
\hline Kegiatan Inti & $\sqrt{ }$ \\
\hline a. Menyampaikan materi sesuai dengan tujuan pembelajaran dan & \\
\hline$\quad$ sistematis. & $\sqrt{ }$ \\
\hline b. Mengaitkan materi dengan realitas kehidupan. & $\sqrt{ }$ \\
\hline c. Menggunakan media dalam menyampaikan materi. & $\sqrt{ }$ \\
\hline c. Melibatkan siswa untuk menjelaskan dan mengerjakan & \\
$\quad$ operasi bilangan. & $\sqrt{ }$ \\
\hline e. Adanya interaksi dalam pembelajaran &
\end{tabular}


Jurnal PAJAR (Pendidikan dan Pengajaran)

Volume 5 Nomor 6 November | ISSN Cetak : 2580 - 8435| | ISSN Online : 2614 - 1337

DOI : http://dx.doi.org/10.33578/pjr.v5i6.8582

f. Memudahkan siswa untuk melakukan proses mengamati berkaitan dengan operasi bilangan.

g. Memfasilitasi siswa untuk melakukan latihan dengansoalsoal secara tertulis atau lisan.

h. Guru memantau latihan yang dilakukan siswa

i. Mengkonfrimasi hal-hal yang belum diketahui siswadan memberikan penguatan kepada siswa.

$3 \quad$ Kegiatan Penutup

a. Merangkum materi $\sqrt{ }$

b. Guru melakukan refleksi terhadap pembelajaran.

c. Guru memberikan soal evaluasi.

d. Guru memberikan tindak lanjut.

e. Menutup pembelajaran dengan doa dan salam

Pada akhir pembelajaran siklus II guru memberikan soal evaluasi tentang operasi bilangan, berikut disajikan hasil belajar siswa berdasarkan hasil soal evaluasi yang dikerjakan.

Tabel 4. Hasil Belajar Siklus II

\begin{tabular}{ccccc}
\hline No & Nilai (x) & $\begin{array}{c}\text { Frekuensi } \\
\text { (f) }\end{array}$ & $\mathbf{f x}$ & Presentasi \\
\hline 1 & 50 & 0 & 0 & $0 \%$ \\
2 & 75 & 4 & 300 & $38 \%$ \\
3 & 80 & 3 & 240 & $28 \%$ \\
4 & 85 & 3 & 255 & $28 \%$ \\
5 & 90 & 1 & 90 & $6 \%$ \\
6 & 100 & 0 & 0 & $0 \%$ \\
7 & 0 ( Tidak Menjawab) & 0 & 0 & $0 \%$ \\
& Jumlah & 11 & 885 & $100 \%$ \\
\hline
\end{tabular}

\section{Pembahasan}

Pada penelitian ini dilaksanakan tindakan pada dua siklus yaitu, pada setiap siklusnya didapatkan data mengenai perencanaan pembelajaran, pelaksanaan pembelajaran, hasil belajar siswa dan respon siswa terhadap, pembelajaran. Berdasarkan pengamatan pada siklus I terlihat bahwa guru melakukan perencanaan dengan membuat perangkat pembelajaran meliput RPP, LKPD, dan Media Pembelajaran. Adapun perangkat yang dibuat guru dengan memasukkan tindakan yang akan dilakukan saat penelitian.

Pada tabel 1 guru memberikan pembelajaran matematika pada operasi bilangan. Terlihat pada kegiatan pembuka guru melakukan semua komponen kecuali motivasi. Selain itu guru juga tidak melakukan tindakan pada kegiatan inti yaitu pada bagian mengamati operasi bilangan, dan tidak memantau latihan kegiatan siswa. Sedangkan pada kegiatan penutup guru tidak melakukan refleksi pada pembelajaran. Sehingga pada hasil belajar siswa pada siklus I rendah yang termotivasi mengikuti pelajaran matematika pada operasi bilangan hanya 10 orang, 4 orang memproleh nilai 50, 3 orang memperoleh nilai 75 , 3 orang 80 memiliki presentase $94 \%$, sedangkan 1 orang lagi tidak menjawab pertanyaan, dengan rata-rata 60.45 .

Berdasarkan pengamatan pada siklus II juga terlihat bahwa guru melakukan perencanaan dengan membuat perangkat pembelajaran meliput 
RPP, LKPD, dan Media Pembelajaran. Adapun perangkat yang dibuat guru dengan memasukkan tindakan yang akan dilakukan saat penelitian. Pada siklus II ini guru memberikan semua tindakan pada setiap komponen baik pada kegiatan pembukaan, kegiatan inti dan kegiatan penutup. Sehingga pada hasil belajar siswa pada siklus II sangat tinggi untuk mengikuti pelajaran matematika pada operasi bilangan dengan nilai yang memuaskan yaitu, 4 orang memperoleh nilai 75,3 orang memperoleh nilai 80,3 orang memperoleh nilai 85 , dan 1 orang memperoleh nilai 90 , dengan rata-rata 80.45 .

Dalam hal ini pembelajaran dibutuhkan peran guru dalam memfasilitasi siswa untuk mengamati, merefleksi setiap pembelajaran yang diberikan. Proses pembelajaran tidak akan lepas dari peran guru sebagi fasilitor yang membawa konsekuensi terhadap perubahan pola hubungan guru siswa, yang semula lebih bersifat atasan bawahan beralih menjadi hubungan kemitraan (Karsono, 2021). Selain itu juga kompetensi dari guru juga berpengaruh dalam melakukan pembelajaran kepada para siswa baik daring maupun luring, hal ini sependapat dengan penelitian Herlina (2018), menyatakan bahwa kompetensi guru dapat dimaknai sebagai kebulatan pengetahuan, keterampilan dan sikap yang berwujud tindakan cerdas dan penuh tanggung jawab dalam melaksanakan tugas sebagai pelaksana pembelajaran.

Selain itu pemanfaatan pembelajaran menggunakan Google meet sangat tepat pada masa pandemi ini, karena Google meet merupakan aplikasi yang mempermudah guru dan peserta didik dalam melakukan pembelajaran (Juniartini, \& Rasna, 2020). Serta adanya peranan orangtua dalam melakukan pembelajan yang dilaksanakan, karena peranan orangtua sangat penting dalam pembelajaran daring ini, dalam mendukung dan memberikan arahan untuk menggunakan aplikasi Google meet. Hal ini sejalan dengan penelitian Martiyana, Jamaludin, dan Rahman (2021), bahwa pembelajaran daring harus melibatkan orang tua dalam proses pembelajaran.

\section{SIMPULAN DAN REKOMENDASI}

Kesimpulan dalam penelitan ini bahwa pembelajaran yang dilakukan oleh guru menggunakan aplikasi google meet sebagai sarana menyampaikan kegiatan terlihat efektif dalam meningkatkan kemampuan guru pada keterampilan mengajar, terlihat dari pencapaian rata-rata siswa, bila diberikan tindakan setiap komponen kegiatan yang dilakukan. Hal ini juga dubutuhkan peranan, kompetensi dari guru dalam pembelajaran.

Saran untuk guru lebih memberikan pembelajaran yang menarik dalam pembelajaran daring pada masa pandemi ini, agar peserta didik lebih memperhatikan, mengamati, dan mereflesikan pada pembelajaran yang dilaksanakan.

\section{DAFTAR PUSTAKA}

Arikunto, S. (2002). Prosedur Penelitian Suatu Pendekatan Praktek. Jakarta: Rineksa Cipta.

Herlina, H. (2018). Meningkatkan Kompetensi Guru Dalam Menyusun Model Pembelajaran Melalui Workshop Di SD Negeri 009 Seberang Teluk Kecamatan Kuantan Tengah Kabupaten Kuantan Singingi. Jurnal PAJAR (Pendidikan dan Pengajaran), 2(5), 812- 819

Juniartini, N. M. E. \& Rasna, I. W. (2020). Pemanfaatan Aplikasi Google Meet Dalam Keterampilan Menyimak Dan Berbicara Untuk Pembelajaran Bahasa Pada Masa Pandemi Covid-19. Jurnal Pendidikan dan Pembelajaran Bahasa Indonesia, 9(1), 133-141

Karsono. (2021). Implementing Workshops To Improve Teachers' Ability To Utilize Computers In Teaching Process At Smp Negeri 1 Kubu Rokan Hilir. Primary: Jurnal Pendidikan Guru Sekolah Dasar, $10 \quad$ (1), $243 \quad-\quad 250$. DOI:http://dx.doi.org/10.33578/jpfkip.v10 i1.8228.

Koesmini, Astien Diena. (2021). Penerapan Model Pembelajaran Kooperatif Jigsaw Menggunakan Zoom Meeting Untuk Meningkatkan Prestasi Belajar 
Jurnal PAJAR (Pendidikan dan Pengajaran)

Volume 5 Nomor 6 November | ISSN Cetak : 2580 - 8435| | ISSN Online : 2614 - 1337

DOI : http://dx.doi.org/10.33578/pjr.v5i6.8582

Matematika Tentang Bilangan Bulat Siswa

Kelas Vi Uptd Sdn Mlajah 2 Semester I

Tahun Pelajaran 2020/2021. Jurnal

Pendidikan Lampu. ISSN : 2460-8017. 59-

75

Martiyana, E. P., Jamaludin, U., \& Rahman, I. U. (2021). Teachers' Role in Building the Character of Confidence in Online-Based Thematic Learning. Primary: Jurnal Pendidikan Guru Sekolah Dasar, 10 (1), 79 - $93 . \quad$ DOI: http://dx.doi.org/10.33578/jpfkip.v10i1. $\underline{8076}$.

Pernantah, Piki Setri., Nova., \& Ramadhani, Annisa Suci. (2021). Penggunaan Aplikasi Google meet dalam Menunjang Keefektifan Belajar Daring Masa Pandemi Covid-19 di SMA Negeri 3 Pekanbaru. Pedagogi Jurnal Ilmu Pendidikan, 21(1), 45-50.

DOI:https://doi.org/10.24036/pedagogi.v2 $\underline{1 \mathrm{i} 1.991}$

Thowaf, Indah Pinakesti. (2018). Penggunaan Aplikasi Whatsapp Dan Google Meet Dalam Upaya Meningkatkan Hasil Belajar Matematika Pada Siswa Kelas V Sd Negeri 1 Banarankulon. Lomba Nasional PTK Jenjang SD. ISBN : 978-623-9753-0-7. 218-226 